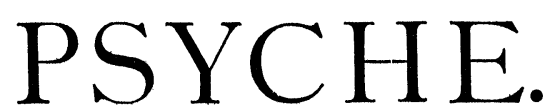

ORGAN OF THE CAMBRIDGE ENTOMOLOGICAL CLUB. EDITED BY B. PICKMAN MANN.

Vol. I.] Cambridge, Mass., March, 1875. [No. 11.

\title{
Description of the Larva of Galerita Janus.
}

Head of medium size, flat, semicircular, somewhat enlarged anteriorly, with a short, cylindrical basal neck; above, sparingly covered with short black hairs; depressed in the middle; sides and base rounded, convex; branches of the $\mathrm{Y}$ suture protruded interiorly in the middle, where a small black dot is to be seen, ending inside of the elevated, somewhat cylindrical, anterior angles of the head, where the antennæ are inserted; above the anterior border, a horny prolongation nearly as long as the head, conical at the base, the apical half bifurcated, each branch with two bristles on the under surface, one nearly terminal, the other a short distance behind the first; just belind the insertion of the antennæ, six oval ocelli arranged around a low, conical elevation, in two transverse series, the middle pair more widely separate than the upper or lower ones; on the upper surface of the head, within and behind the ocelli, on each side, a longer bristle; head beneath flat; on each side near the base, two bristles on short pointed tubercles.

Antennæ twice as long as the head, of four cylindrical joints, the first nearly equal to the two following united, the second half as long, and the third more than half as long as the first, the fourth very small, lozenge-shaped; the first and second straight the first with three equidistant interior bristles and two internal and two or three external finer bristles near the apex, the second with one prominent and several finer bristles, the third and fourth joints bent downwards and outwards, with more numerous, very long and fine hairs, in the fourth inserted upon two internal, one external and one terminal tubercles.

Labrum rudimentary, a small, transverse plate, turned back, with rounded angles and under surface densely covered with 
minute hooks; two acute teeth each side on the head, beneath the bifurcated prolongation, one near the labrum, the other further off and nearer the border.

Mandibles longer than the head, sickle-shaped, pointed, with a stout internal tooth near the middle.

Maxillæ cylindrical, about as thick and as long as the first joint of the antennæ, slightly curved inwards, bearing midway a stout external bristle, and near the apex two or three internal and one external bristles, the whole joint scatteringly covered with fine short hairs, the extremity with two appendages, the external, or palpus, of four joints increasing slightly in length, the first two bearing one or two bristles, the last two without hairs, the internal, or maxillary lobe, of two joints, the terminal long, slender and pointed, each with a bristle.

Labium with an elongated mentum and two diverging, elongated, cylindrical palpus-bearing pieces united nearly to their apices by a membrane prolonged beyond them in a fleshy ligula, terminating in a bristle ; labial palpi of two joints, the first once and a half as long as the second.

Thoracic segments above, horny, flattened, covered with short pubescence.

Prothorax elongated, narrow in front, gradually enlarged, widest shortly before the base, where it equals the head in width; angles rounded; on each side of the median line several scar-like depressions.

Mesothorax and metathorax together as long as the prothorax, somewhat broader, narrowed before, with rounded angles; mesothorax a little longer and narrower than the metathorax; both with slight depressions on each side.

Abdomen as long as the head and thorax together, flattened, in the middle as wide as the prothorax, gradually narrowed before and behind; segments with horny, transverse shields above and below, finely rugose, and scatteringly covered with short, spiny hairs, more conspicuous at the borders; the terminal, ninth segment shorter and narrower than the others, with a tubular anus, and two very long, filiform appendages of more than twenty-five very unequal articulations, each furnished with a bristle (apex wanting). 
Stigmata nine pairs, the first, upon the mesothorax, very large, oblong, oblique, visible from below, the others on segments one to eight of the abdomen, the first oval, half as large as the mesothoracic, the rest small, circular.

Legs slender, half as long as the body, increasing in length posteriorly ; femora stout, anterior longest, flattened anteriorly ; tibiæe cylindrical, about as long as the femora ; tarsi cylindrical, longer than the tibix, the two joints equal in length, the terminal slender, tapering uniformly, with two small apical hooks; legs, except the anterior femora, hairy, more densely on the terminal joints.

Femora of the fore legs with four strong, straight spines on the anterior border, united at their bases and tipped with a bristle, the three anterior subequal, the fourth smaller, the two anterior closer together. Tibiæ of fore legs obsoletely serrate posteriorly, with four or five bristle-bearing denticulations.

Length, exclusive of appendages, 17 millimetres.

Body very dark brown, opaque, having in life a bluish reflection as in the imago, the head and prothorax honey yellow, with a faint brown patch in front of the eyes, and the first two joints of the antennæ more or less darkened, especially towards their apices, the prothorax with a dark brown transverse band, deeply tri-lobed posteriorly, divided by the median furrow, not quite attaining the border on the sides, and covering the apical third. The fore legs clear yellow, like the head and prothorax, the terminal joint uniformly darkened, and the two preceding only towards their apices. The remaining legs dark brown, testaceous at the joints. The long first joint of the terminal appendages clear yellow, the succeeding joints dark brown except at their junction with each other.

This description is made from three larvæ preserved in alcohol, and the skin of a fourth from which the imago was raised, none of which have the caudal appendages entire. They were found in the latter part of July, at Detroit, Michigan, under the loose bark of damp and rotten logs, where by the 16th of August the pupæ were found in unlined cells, formed by the movement of the larve. Two days later the imago appeared.

On comparison with a larva from Kansas, probably of $G$. 
atripes or $G$. bicolor, in the alcoholic collection of the Museum of Comp. Zoöl. at Cambridge, I can find but slight differences. The Kansas species is somewhat more elongated in all its parts, and the spines of the anterior femora are slightly curved backwards; the dark band on the prothorax is much reduced in size, and the caudal appendages are more testaceous ; they have thirtythree articulations. The specimen is much denuded of its bristles, but those that remain correspond in position with those of G.janus. In general, the characters given by Chapuis and Candèze for $G$. Lecontei agree with those of $G$.janus, but many of the details given above for $G$.janus are not mentioned in the description of $G$. Lecontei. Salle's figure of the latter, reproduced in Paokard's "Guide", is certainly unreliable, and strangely exaggerated in the attenuation of its parts. The larva figured in the "Guide", Appendix, p. 713, fig. 667, cannot be a Galerita.

H. G. Hubbard.

\section{BIBLIOGRAPHICAL RECORD.}

Authors and Societies are requested to forward their works to the Editor at the earliest date possible. We ask our readers to inform us of the publication especially of those works which are not generally consulted by entomologists.

B. Pickman Mann.

(Continued from page 48.)

The Annales de la Societe Entomologique de France, ser. 5, vol. iii (1873), from p. 395, contain Nos. 131, 132.

* 131. V. Srønoret. Essai sur les Cochenilles ou Gallinsectes (Homoptères - Coccides) 11e partie. p. 395-448, tab. $12,13$.

Describes 52 (14 new, 37 figured) species of Lecanium, of which 10 (3 new, 5 figured) are North American; classiftcation; habits.

* 132. Al. Laboulbene et Ch. Robin. Observations sur les Organes lumineux du Pyrophorus nootituous Linné. p. 529536 .

Structure, histology, ohemical camposition and physiological action of these organs.

* 133. The Bulletin de Ia Soc. Entom. de France, année 1873, from p. exciii, contains the following.

a. The generic name Bromius must yield to the name Adoxus (by Edouard Lefèvre), p. excr-cxcvi. b. Synonymy and habitat of Clytus cinereus (by Finest Olivier), p. cexxvii. c. List of the 375 (7 N. A.) mem- 

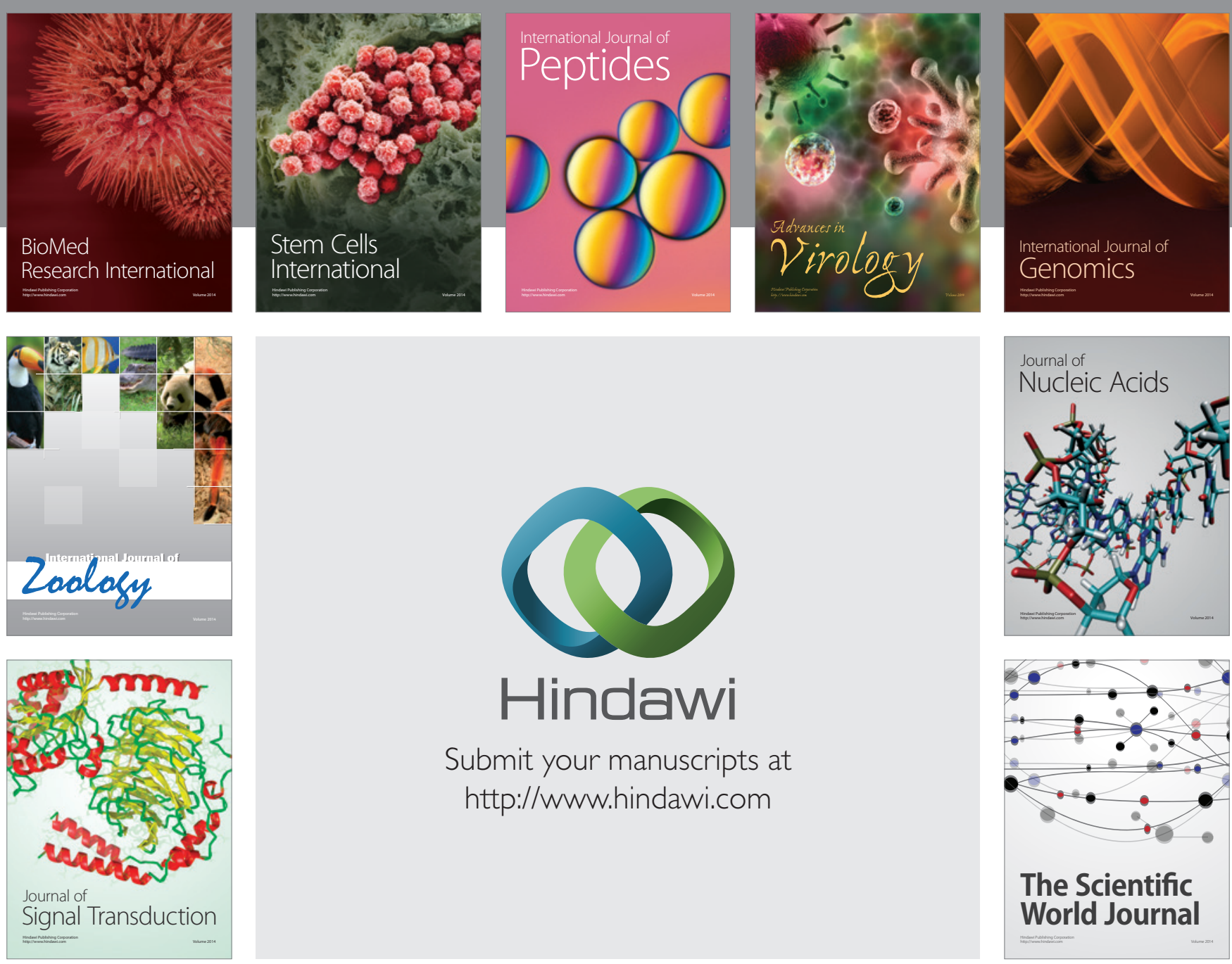

Submit your manuscripts at

http://www.hindawi.com
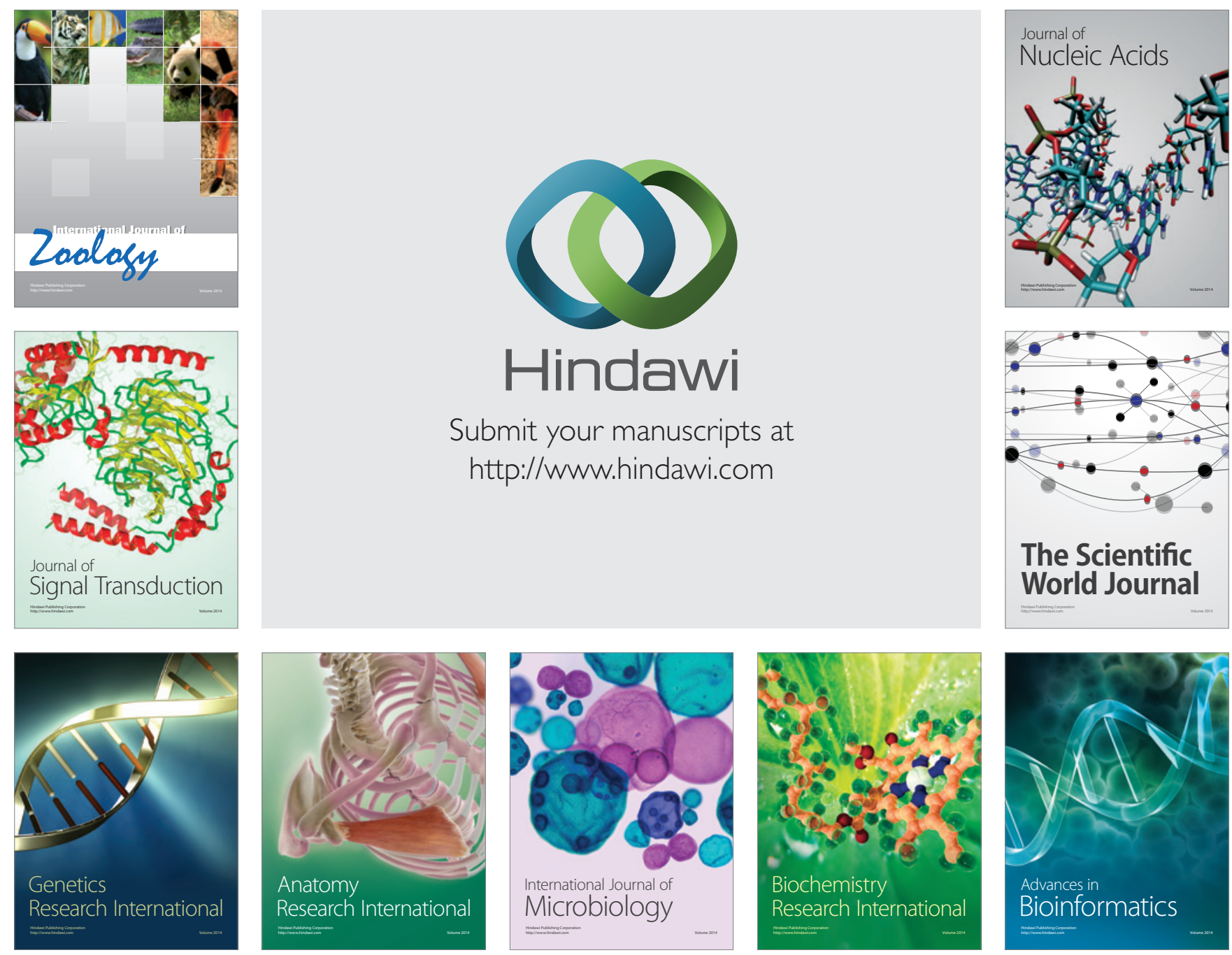

The Scientific World Journal
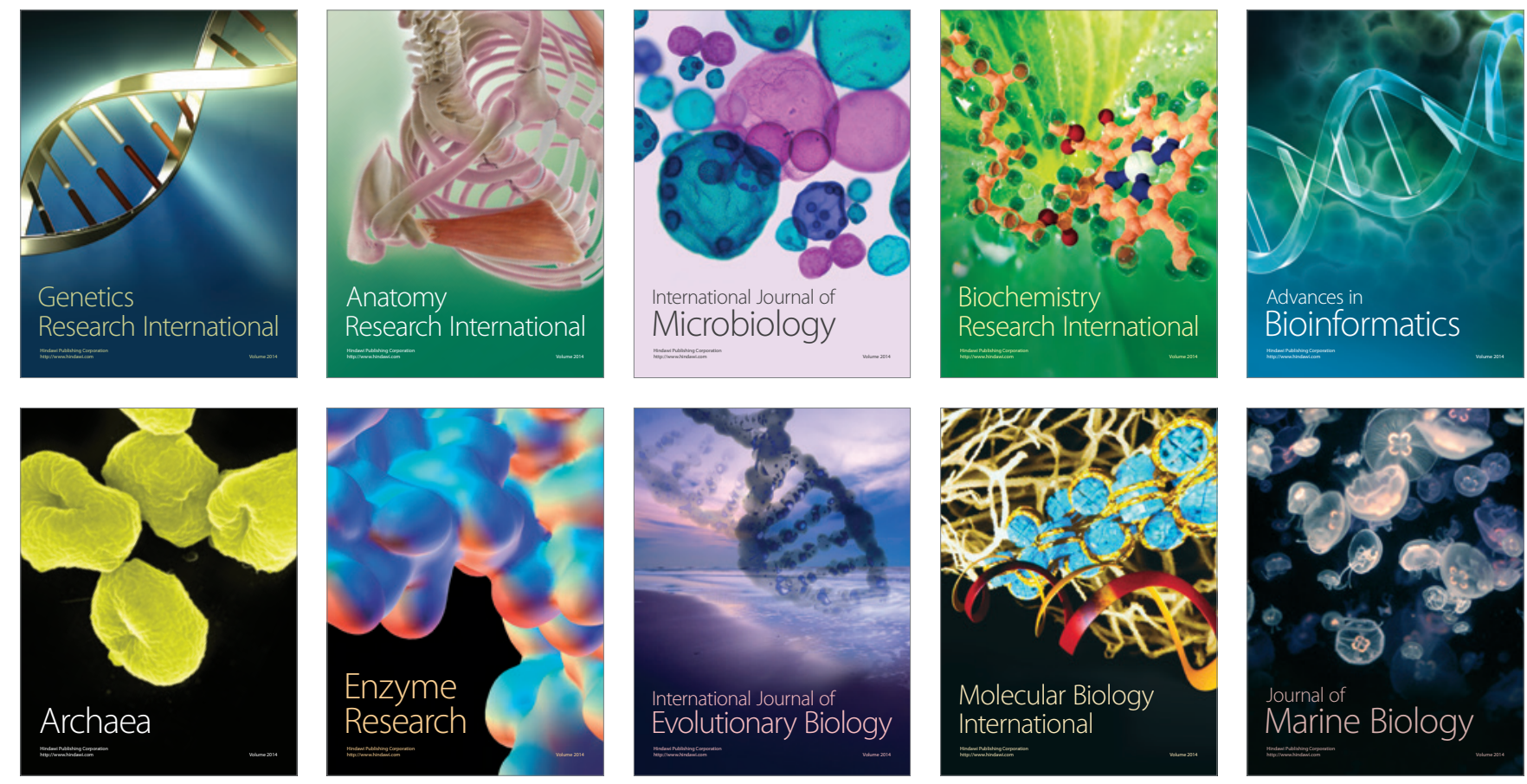